\title{
Prevalence of Vitamin D Deficiency Among Iranian Pregnant Women
}

This article was published in the following Dove Press journal:

Nutrition and Dietary Supplements

\author{
Mojtaba Sepandi (D) \\ Simindokht Esmailzadeh ${ }^{2}$ \\ Mahboobeh Sadat Hosseini ${ }^{1}$ \\ Seyedeh Razieh Hashemi ${ }^{3}$ \\ Sepideh Abbaszadeh (D) \\ Yousef Alimohamadi (iD) \\ Maryam Taghdir (D) ${ }^{1,2}$ \\ 'Health Research Center, Life Style \\ Institute, Baqiyatallah University of \\ Medical Sciences, Tehran, Iran; \\ ${ }^{2}$ Department of Nutrition and Food \\ Hygiene, Faculty of Health, Baqiyatallah \\ University of Medical Sciences, Tehran, \\ Iran; ${ }^{3}$ Trauma Research Center, \\ Baqiyatallah University of Medical \\ Sciences, Tehran, Iran; ${ }^{4}$ Pars Advanced \\ and Minimally Invasive Medical Manners \\ Research Center, Pars Hospital, Iran \\ University of Medical Sciences, Tehran, \\ Iran; ${ }^{5}$ Department of Epidemiology \& \\ Biostatistics, School of Public Health, \\ Tehran University of Medical Sciences, \\ Tehran, Iran
}

Correspondence: Maryam Taghdir Health Research Center, Life Style Institute, Baqiyatallah University of Medical Sciences, Tehran, Iran

Email mtaghdir@bmsu.ac.ir
Background: Vitamin D deficiency (VDD) is a common concern. A high prevalence of VDD has been reported among pregnant women in different countries. The aim of this study was to assess the prevalence of VDD in the first trimester of pregnancy.

Methods: This cross-sectional study was conducted on 267 pregnant women (before 14 weeks of gestation). The level of 25-hydroxyvitamin D $(25(\mathrm{OH}) \mathrm{D})$ was measured. Demographic data (age, educational level, season of blood sampling, and vitamin D supplementation intake) were collected using a questionnaire.

Results: Based on the results of the study, 205 out of 267 subjects (76.8\%) had deficient vitamin D levels (<20 ng/mL), $39(14.6 \%)$ had insufficient levels $(20-29 \mathrm{ng} / \mathrm{mL})$, and 23 $(8.6 \%)$ had sufficient levels ( $\geq 30 \mathrm{ng} / \mathrm{mL}$ ). In addition, 133 women $(49.8 \%)$ had severe VDD. VDD was more prevalent in autumn/winter than in spring/summer $(P=0.03)$. The prevalence of VDD was higher among the younger age group than in the older group $(P=0.04)$. In multivariate analysis, the only variable that was significantly associated with low vitamin D status was taking supplements. Those who were not receiving vitamin D supplements had higher odds of VDD status (adjusted odds ratio=77.3, 95\% CI 23.9-249.6).

Conclusion: VDD is a public health problem in the first trimester of pregnancy. Greater awareness among healthcare providers and the community is required for prevention and appropriate treatment.

Keywords: pregnancy, vitamin D deficiency, vitamin D insufficiency

\section{Introduction}

Vitamin D deficiency (VDD) is a worldwide public health issue, ${ }^{1}$ which increases the risk of serious diseases, including cancers, cardiovascular diseases, and autoimmune diseases such as type 1 diabetes. $^{2}$ A high prevalence of VDD has been reported among pregnant women and neonates in different countries. ${ }^{3,4}$ The prevalence of VDD in pregnant women varies from $18 \%$ to $84 \%{ }^{4}$ The prevalence of VDD is high in the Middle Eastern countries, such as Iran, Saudi Arabia, and the United Arab Emirates, owing to low exposure to the sun because of cultural factors. ${ }^{2,5}$

The prevalence rates of severe, moderate, and mild VDD among the Iranian adult population have been reported as $26.7 \%, 23.9 \%$, and $19.6 \%$, respectively. ${ }^{6}$ According to the results of a previous study in Iran, about $75.1 \%$ of women and $72.1 \%$ of men were suffering from VDD. ${ }^{6}$

VDD can lead to osteomalacia in pregnancy. Other consequences of VDD in pregnancy include an increased risk of gestational diabetes mellitus, preeclampsia, intrauterine growth retardation, and low birth weight. ${ }^{7,8}$ The present investigation 
has been conducted to study the prevalence of VDD among pregnant women (before 14 weeks of gestation).

\section{Materials and Methods}

\section{Study Design and Sample Size}

This cross-sectional study was conducted in Tehran, Iran, on 267 pregnant women (before 14 weeks of gestation) who visited the Gynaecology and Obstetrics Clinic of Baqiyatallah Hospital for a routine check-up from March 21, 2014 to March 20, 2015. The study size was calculated using the following formula:

$$
n=\frac{z_{\propto}^{2} \times p(1-p)}{d^{2}}=246
$$

where, $\alpha=0.05, d=0.05$, and the prevalence of VDD $(p)=0.8{ }^{9}$

\section{Eligibility Criteria, Variables, and Sampling Method}

The eligibility criteria were pregnant women before 14 weeks of gestation and availability of related data. All of the study participants were residing in Tehran $\left(36^{\circ} 21^{\prime} \mathrm{N}\right)$. The study sample was determined by a systematic random sampling method from all qualifying pregnant women. Demographic data (age, educational level, season of blood sampling, and vitamin $\mathrm{D}$ supplementation intake) were collected using a questionnaire, and body mass index (BMI) was calculated from weight in $\mathrm{kg}$ divided by height in $\mathrm{m}^{2}$. Volumes of about $5 \mathrm{~mL}$ of the fasting blood samples from all study subjects were collected and serum was separated via centrifugation (Sigma 4-16KHS) at $3500 \mathrm{rpm}$ for 10 minutes. The serum level of 25-hydroxyvitamin D $(25(\mathrm{OH}) \mathrm{D})$ was measured using the chemiluminescent immunoassay (CLIA) method (Liaison® 25-OH Vitamin D CLIA kit; DiaSorin, Stillwater, MN, USA); the kit's expected range was 3-150 $\mathrm{ng} / \mathrm{mL}$, which is based on an interassay precision that approximated $20 \% \mathrm{CV}$ (functional sensitivity). A serum vitamin D level $<20 \mathrm{ng} / \mathrm{mL}$ indicates VDD, 20-29 ng/mL indicates suboptimal status, and 30-50 ng/mL indicates an optimal level of 25(OH)D for maximal effect on parathyroid hormone. ${ }^{8,10}$

\section{Statistical Analysis}

The Kolmogorov-Smirnov test was used to evaluate the normality of data distribution. Factors related to VDD were identified through univariate and multivariate logistic regression analysis after adjusting for age (18-29 and 30-39 years), educational level ( $\leq 12$ and $>12$ years), BMI (underweight
$<18.5 \mathrm{~kg} / \mathrm{m}^{2}$, normal $18.5-24.9 \mathrm{~kg} / \mathrm{m}^{2}$, overweight $25-29.9$ $\mathrm{kg} / \mathrm{m}^{2}$, and obese $\geq 30 \mathrm{~kg} / \mathrm{m}^{2}$ ), season of blood sampling (spring/summer and autumn/winter), and vitamin D supplementation intake (yes or no). Age and BMI were considered as continuous variables in logistic regression analysis. The differences were considered significant at $P$-values of less than 0.05. Statistical analysis was conducted using SPSS software (version 16) (SPSS, Chicago, IL, USA).

\section{Ethical Considerations}

This study was approved by the ethics committee of Baqiyatallah University of Medical Sciences (Code: 5904). All subjects provided the study with voluntary informed consent prior to participation. Those who were not willing to participate in the study were not included (two women).

\section{Results}

During the study, 267 pregnant women, aged 18-39 years, were investigated. The mean age was $28.5 \pm 5.0$ years. The median of serum $25(\mathrm{OH}) \mathrm{D}$ concentrations of all participants was $10 \mathrm{ng} / \mathrm{mL}$ (interquartile range $[\mathrm{IQR}]=5.4-18.6$ $\mathrm{ng} / \mathrm{mL}$ ) and the highest reading recorded among subjects was $71.8 \mathrm{ng} / \mathrm{mL}$.

The baseline characteristics of participants are shown in Table 1. The overall prevalence of VDD and vitamin D insufficiency was $76.7 \%$ and $14.6 \%$, respectively. Among them, 140 women $(52.4 \%)$ had severe VDD $(25(\mathrm{OH}) \mathrm{D}<10$ $\mathrm{ng} / \mathrm{mL}$ ). As shown in Table 2, in autumn/winter, VDD was prevalent among $82.3 \%$ of the pregnant women and in spring/summer VDD was prevalent among $71.5 \%$ of the pregnant women $(P=0.03)$. Almost $15 \%$ of participants took vitamin $\mathrm{D}$ as a nutrient supplement. The median level of $25(\mathrm{OH}) \mathrm{D}$ in the age group 30-39 years was higher than in the age group $18-29$ years ( $13.4 \mathrm{vs} 8 \mathrm{ng} / \mathrm{mL}, P=0.0001)$. The prevalence of VDD was higher among the younger age group $(P=0.04)$. The median (IQR) level of $25(\mathrm{OH}) \mathrm{D}$ was 10 (5.217.6) $\mathrm{ng} / \mathrm{mL}$ in participants with a high level of education (>12 years) and $9.1(6.1-18.9) \mathrm{ng} / \mathrm{mL}$ in those with a low level ( $\leq 12$ years). Educated women (with a college degree) had a lower prevalence of VDD than those with lower educational levels ( $75.4 \%$ vs $77.9 \%, P=0.6)$.

The median (IQR) levels of 25(OH)D in spring/summer and autumn/winter were $12.1(5.8-20.7) \mathrm{ng} / \mathrm{mL}$ and $8.3(5.2-16.1) \mathrm{ng} / \mathrm{mL}$, respectively $(P=0.07)$. Many of the participants were overweight $(38.2 \%)$ or obese $(16.9 \%)$. Overweight and obese women had a lower prevalence of VDD ( $74.5 \%$ and $71.1 \%$, respectively) compared to those with normal body weight (82.6\%). 
Table I Baseline Characteristics of 267 Iranian Pregnant Women

\begin{tabular}{|c|c|c|c|}
\hline \multicolumn{3}{|l|}{ Characteristics } & \multirow{2}{*}{$\begin{array}{l}\text { n (\%) } \\
140(52.4)\end{array}$} \\
\hline \multirow[t]{4}{*}{ Vitamin D Status } & \multirow[t]{2}{*}{ SVDD/VDD } & $<10 \mathrm{ng} / \mathrm{mL}$ & \\
\hline & & $10-20 \mathrm{ng} / \mathrm{mL}$ & $65(24.3)$ \\
\hline & \multicolumn{2}{|c|}{ Insufficiency $(20-29 \mathrm{ng} / \mathrm{mL})$} & $39(14.6)$ \\
\hline & \multicolumn{2}{|c|}{ Optimal level (30-50 ng/mL) } & $23(8.6)$ \\
\hline \multirow[t]{2}{*}{ Age (years) } & \multicolumn{2}{|l|}{$18-29$} & $183(68.5)$ \\
\hline & \multicolumn{2}{|l|}{$30-39$} & $84(31.5)$ \\
\hline \multirow[t]{2}{*}{ Season $^{\mathrm{a}}$} & \multicolumn{2}{|c|}{ Spring/summer } & $137(5 \mid .3)$ \\
\hline & \multicolumn{2}{|c|}{ Autumn/winter } & $130(48.7)$ \\
\hline \multirow[t]{2}{*}{ Education (years) } & \multicolumn{2}{|l|}{$\leq 12$} & $149(55.8)$ \\
\hline & \multicolumn{2}{|l|}{$>12$} & $118(44.2)$ \\
\hline \multirow[t]{4}{*}{ BMI $\left(\mathrm{kg} / \mathrm{m}^{2}\right)$} & \multicolumn{2}{|c|}{ Underweight $(<18.5)$} & $109(40.8)$ \\
\hline & \multicolumn{2}{|c|}{ Normal (18.5-24.9) } & II (4.I) \\
\hline & \multicolumn{2}{|c|}{ Overweight (25-29.9) } & $102(38.2)$ \\
\hline & \multicolumn{2}{|l|}{ Obese $(\geq 30)$} & $45(16.9)$ \\
\hline \multirow[t]{2}{*}{ Vitamin D Supplementation } & \multicolumn{2}{|l|}{ Yes } & $39(14.6)$ \\
\hline & \multicolumn{2}{|l|}{ No } & $228(85.4)$ \\
\hline
\end{tabular}

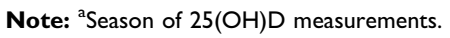

Abbreviations: VDD, vitamin D deficiency; SVDD, severe vitamin D deficiency.

Only $14.6 \%$ of participants reported a history of vitamin D supplementation. About $16.1 \%$ of women with lower educational level and $12.7 \%$ of women with higher educational level had a history of supplementation $(P=0.43)$. Twelve percent of the younger age group and $20.2 \%$ of the older age group had received vitamin D supplements $(P=0.07)$. The relative frequency of taking vitamin D supplements among underweight, normal weight, overweight, and obese pregnant women was $14.7 \%, 18.2 \%, 12.7 \%$, and $17.8 \%$, respectively $(P=0.8)$. The frequency of taking vitamin D supplements was $7.5 \%$ in spring/summer and $11.5 \%$ in autumn/winter ( $P=0.16$ ) (data not shown in the tables).

In multivariate analysis, the only variable significantly related to low vitamin D status was taking supplements. Compared to pregnant women receiving vitamin D supplements, those who were not receiving vitamin D supplements had higher odds of VDD status (adjusted odds ratio $[\mathrm{OR}]=77.3$, 95\% CI 23.9-249.6) (Table 3).

\section{Discussion}

Our findings, which are consistent with previous studies, showed a high prevalence of VDD (76.8\%) among Iranian pregnant women. VDD has previously been reported in Iranian pregnant women at prevalences of $78 \%{ }^{11}$ $70.4 \%,{ }^{12}$ and $69.2 \%{ }^{13}$ The high prevalence of VDD in women has also been observed in other countries. In New Zealand, the Netherlands, and Canada, respectively, 61\%, $60 \%$, and $46 \%$ of pregnant women were vitamin D deficient. $^{14-16}$

Vitamin D status is typically influenced by factors such as latitude, season of the year, time of day, and air pollution. ${ }^{17}$ Tehran ranks among the most populated cities in the world and this makes its inhabitants susceptible to VDD. Increased accommodation in apartments because of the increased population of the city and air pollution are among the factors limiting exposure to the sun in Tehran. Tehran is a sunny city, but with limited direct exposure to the sun.

Some studies have reported a higher prevalence of VDD among elderly people, ${ }^{18}$ whereas, in the present study, as in another study conducted in Tehran, ${ }^{19}$ the prevalence of VDD was higher among the younger age group. This may be due to lifestyle modifications among younger people. Younger people favor living in apartments and using electronic devices such as mobile phones and tablets, so they take less physical activity in the open air. Moreover, to prevent skin disorders, many young women like to apply anti-solar creams to their face. VDD among adolescents has been reported at higher rates in polluted areas than in non-polluted areas. ${ }^{20}$ In 2017 , Feizabad et al conducted a population-based study on 325 students in Tehran in the winter and reported that more than half of the students $(52.9 \%)$ suffered from VDD $(25(\mathrm{OH}) \mathrm{D}$ $<20 \mathrm{ng} / \mathrm{mL}$ ). VDD was more than twice as prevalent in girls (74.4\%) as in boys and VDD was more prevalent in polluted areas than in non-polluted areas. ${ }^{20}$ According to cultural aspects, in Iran and other Muslim countries, women wear a scarf and long-sleeved clothes. The prevalence of VDD was $50 \%$ among pregnant Saudi women, in an area highly exposed to the sun. ${ }^{21}$ It should be noted the assessment of vitamin $\mathrm{D}$ status is important not only in pregnant women, but also in adolescents and young people.

In this study, the median serum $25(\mathrm{OH}) \mathrm{D}$ concentration of all participants was $10 \mathrm{ng} / \mathrm{mL}$. In a study in Norway on five main immigrant groups, including Iranians, the median serum $25(\mathrm{OH}) \mathrm{D}$ level was $10.8 \mathrm{ng} / \mathrm{mL}$ in Iranian women. ${ }^{22}$

The median level of of vitamin D was higher in summer than in winter, showing that season, as an environmental factor, is capable of affecting the VDD. In the present study, the prevalence of VDD was significantly higher in autumn/winter than in spring/summer. These results are similar to those of preceding studies in China, Iran, and 
Table 2 Maternal Characteristics and Vitamin D Status of 267 Iranian Pregnant Women

\begin{tabular}{|c|c|c|c|c|c|}
\hline \multicolumn{2}{|l|}{ Characteristics } & \multirow{2}{*}{$\begin{array}{l}\text { VDD (\%) } \\
80.3 \\
69\end{array}$} & \multirow{2}{*}{$\frac{P \text {-value }}{0.04}$} & \multirow{2}{*}{$\begin{array}{l}\text { SVDD (\%) } \\
60.7 \\
34.5\end{array}$} & \multirow{2}{*}{$\frac{P \text {-value }}{<0.001}$} \\
\hline Age (years) & $\begin{array}{l}18-29 \\
30-39\end{array}$ & & & & \\
\hline Season $^{\mathrm{a}}$ & $\begin{array}{l}\text { Spring/summer } \\
\text { Autumn/winter }\end{array}$ & $\begin{array}{l}71.5 \\
82.3\end{array}$ & 0.03 & $\begin{array}{l}46.7 \\
58.5\end{array}$ & 0.05 \\
\hline Education (years) & $\begin{array}{l}\leq 12 \\
>12\end{array}$ & $\begin{array}{l}77.9 \\
75.4\end{array}$ & 0.6 & $\begin{array}{l}51.0 \\
54.2\end{array}$ & 0.6 \\
\hline BMI $\left(\mathrm{kg} / \mathrm{m}^{2}\right)$ & $\begin{array}{l}\text { Underweight }(<18.5) \\
\text { Normal }(18.5-24.9) \\
\text { Overweight }(25-29.9) \\
\text { Obese }(\geq 30)\end{array}$ & $\begin{array}{l}63.6 \\
82.6 \\
74.5 \\
71.1\end{array}$ & 0.2 & $\begin{array}{l}56.0 \\
27.3 \\
54.9 \\
44.4\end{array}$ & 0.19 \\
\hline Vitamin D Supplementation & $\begin{array}{l}\text { Yes } \\
\text { No }\end{array}$ & $\begin{array}{l}10.3 \\
88.9\end{array}$ & 0.001 & $\begin{array}{l}0 \\
61.4\end{array}$ & $<0.001$ \\
\hline
\end{tabular}

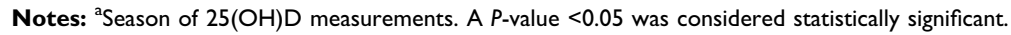
Abbreviations: VDD, vitamin D deficiency $(<20 \mathrm{ng} / \mathrm{mL})$; SVDD, severe vitamin D deficiency $(<10 \mathrm{ng} / \mathrm{mL})$.

Greece. $^{23-25}$ Kull et al argued that the mean serum $25(\mathrm{OH}) \mathrm{D}$ concentration in winter was meaningfully lower than in summer among the general population of Estonia. ${ }^{26}$

Our results, similarly to a previous study in Iran, ${ }^{27}$ indicated no substantial relationship between vitamin $\mathrm{D}$ status and the level of education. But, in contrast to our results, Atiq et al reported a significantly higher level of $25(\mathrm{OH}) \mathrm{D}$ in uneducated mothers in Pakistan, ${ }^{28}$ and another study in Norway, on five immigrant groups in Oslo, reported a positive relationship between education and vitamin $\mathrm{D}$ level in women born in Turkey and Iran. ${ }^{29}$ Educated women may be consuming vitamin D-fortified food or be more exposed to sunlight. Factors such as style of clothing, air pollution, insufficient vitamin D intake, and lack of routine enrichment of foods with vitamin D in Iran could account for the results of our study. ${ }^{19,23}$

The results of the present study, in line with other studies, ${ }^{30,31}$ showed that severe VDD was more prevalent among overweight and obese than in normal weight pregnant women. Therefore, it is more important to assess the vitamin $\mathrm{D}$ status in obese or overweight pregnant women.

According to the results of this study, after adjusting for other variables, taking vitamin D supplements was the only variable that was significantly related to vitamin $\mathrm{D}$ status. Vitamin D was taken by $14.6 \%$ of participants as a nutrient supplement. Compared to pregnant women taking vitamin D supplements, those not receiving vitamin D supplements had higher odds of VDD status (adjusted OR=77.3, 95\% CI 23.9249.6). This wide confidence interval may be due to the low number of pregnant women taking supplements. Vitamin D supplementation in pregnant women could be the most effective way to obtain adequate vitamin D. Unfortunately, however, vitamin D supplementation is not part of most of the ordinary pregnancy care programs in Iran and physicians have not reached a consensus in terms of the consumption of specific vitamin D supplementation. This disagreement is to some extent due to insufficient data on vitamin D status, vitamin D supplementation, and their links with pregnancyrelated results to develop recommendations in Iran. Although the potential impact of VDD during pregnancy on maternal health has been much discussed recently, a contributing link between VDD during pregnancy and opposing pregnancyrelated results should be determined using Hill's criteria. ${ }^{32}$

Because the most important source of vitamin $D$ is sunlight, 10-15 minutes of sun exposure two to three times a week is highly recommended to absorb a suitable amount of vitamin D for women of childbearing age. Also, eating fortified foods that contain vitamin $\mathrm{D}$ is helpful to prevent VDD.

Table 3 Crude and Adjusted Odds Ratio for Vitamin D Deficiency in 267 Iranian Pregnant Women

\begin{tabular}{|c|c|c|}
\hline Characteristics & $\begin{array}{l}\text { Crude Odds Ratio (95\% } \\
\text { Cl) }\end{array}$ & $\begin{array}{l}\text { Adjusted Odds Ratio } \\
(95 \% \mathrm{Cl})\end{array}$ \\
\hline Age & $0.9(0.8-0.9)$ & $0.9(0.8-1.0)$ \\
\hline $\begin{array}{l}\text { Autumn/winter } \\
\text { season }\end{array}$ & $1.8(1.1-3.3)$ & $1.93(0.8-4.2)$ \\
\hline $\begin{array}{l}\text { Education } \leq 12 \\
\text { years }\end{array}$ & I.I $(0.6-2.0)$ & $1.7(0.8-3.8)$ \\
\hline BMI & $0.9(0.9-1)$ & $0.94(0.8-1.0)$ \\
\hline $\begin{array}{l}\text { No } \\
\text { supplementation }\end{array}$ & $65.14(21.50-197.60)$ & $77.3(23.9-249.6)$ \\
\hline
\end{tabular}


Since the hospital in which the study was conducted is one of the largest referral hospitals in Tehran, the results of this study could be generalized to the urban population. Our study also has several limitations that should be addressed in future investigations. These include ignoring the dietary vitamin D intake measurement, extent of exposure to sunlight, and other likely risk factors for VDD.

\section{Conclusions}

According to our results, VDD is a significant public health problem in the first trimester of pregnancy. The investigation of vitamin D nutritional status in pregnant women and increased awareness among healthcare providers could help to prevent the adverse effects of VDD as well as assist in choosing good treatments.

\section{Acknowledgements}

We acknowledge the personnel of Gynecology \& Obstetrics Clinic of Baqiyatallah Hospital for their assistance. The authors would like to thank the Clinical Research Development Unit of Baqiyatallah Hospital for the guidance and advice.

\section{Abbreviations}

VDD, vitamin D deficiency; IQR, interquartile range.

\section{Ethics/Copyright}

This study was approved by the ethics committee of Baqiyatallah University of Medical Sciences (Code: 5904). All subjects provided the study with voluntary informed consent prior to participation. Those who were not willing to participate in the study were excluded.

\section{Author Contributions}

All authors made a significant contribution to the work reported, whether in the conception, study design, execution, acquisition of data, analysis and interpretation, or in all these areas; took part in drafting, revising or critically reviewing the article; gave final approval of the version to be published; have agreed on the journal to which the article has been submitted; and agree to be accountable for all aspects of the work.

\section{Funding}

This research did not receive any specific grant from funding agencies in the public, commercial, or not-forprofit sectors.

\section{Disclosure}

The authors report no conflicts of interest in this work.

\section{References}

1. Holick MF. High prevalence of vitamin D inadequacy and implications for health. Paper presented at: Mayo Clinic Proceedings; 2006.

2. Dawson-Hughes B, Heaney RP, Holick MF, Lips P, Meunier PJ, Vieth R. Estimates of Optimal Vitamin D Status. Springer; 2005.

3. Saraf R, Morton SM, Camargo CA Jr, Grant CC. Global summary of maternal and newborn vitamin D status-a systematic review. Matern Child Nutr. 2016;12(4):647-668. doi:10.1111/mcn.12210

4. Hajizadeh S, Shary JR, Reed SG, Wagner CL. The prevalence of hypovitaminosis $\mathrm{D}$ and its risk factors in pregnant women and their newborns in the Middle East: a systematic review. Int $J$ Reprod Biomed. 2019;17(10):685.

5. Kovacs CS. Calcium and bone metabolism in pregnancy and lactation. J Clin Endocrinol Metab. 2001;86(6):2344-2348. doi:10.1210/ jcem.86.6.7575

6. Mirhashemi S, Kalantar Motamedi M, Mirhashemi A, Taghipour H, Danial Z. Vitamin D deficiency in Iran. Int J Med Rev. 2017;4(3):6465. doi:10.29252/ijmr-040301

7. Fiscaletti M, Stewart P, Munns C. The importance of vitamin D in maternal and child health: a global perspective. Public Health Rev. 2017;38(1):1-17. doi:10.1186/s40985-017-0066-3

8. Dawodu A, Akinbi H. Vitamin D nutrition in pregnancy: current opinion. Int J Womens Health. 2013;5:333. doi:10.2147/IJWH.S34032

9. Kazemi A, Sharifi F, Jafari N, Mousavinasab N. High prevalence of vitamin $\mathrm{D}$ deficiency among pregnant women and their newborns in an Iranian population. $J$ Womens Health. 2009;18(6):835-839. doi:10.1089/jwh.2008.0954

10. Munns CF, Mairead Kiely NS, Specker BL, et al. Global consensus recommendations on prevention and management of nutritional rickets. J Clin Endocrinol Metab. 2016;101(2):394-415. doi:10.1210/ jc.2015-2175

11. Azar Pirdehghan MV, Dehghan R, Zare F. High prevalence of vitamin D deficiency and adverse pregnancy outcomes in yazd, a Central Province of Iran. J Reprod Infertil. 2016;17(1):34.

12. Amouzegar A, Azizi F, Ashrafivand S, et al.Prevalence of calcium and vitamin D deficiency and their association with feto-maternal outcomes in a sample of Iranian pregnant women. Hum Antibodies. 2020;(Preprint):1-6. doi:10.3233/HAB-200415

13. Mirbolouk F, Pakseresht S, Asgharnia M, Farjadmand BM, Kazemnezhad E. Study of vitamin D status in pregnant women in north of Iran. Int J Womens Health Reprod Sci. 2016;4(4):176-180. doi:10.15296/ijwhr.2016.39

14. Judkins A, Eagleton C. Vitamin D deficiency in pregnant New Zealand women. N Z Med J. 2005;119(1241):U2144-U2144.

15. van der Meer IM, Karamali NS, Boeke AJP, et al. High prevalence of vitamin D deficiency in pregnant non-western women in The Hague, Netherlands. Am J Clin Nutr. 2006;84(2):350-353. doi:10.1093/ajen/ 84.2.350

16. Ward LM. Vitamin D deficiency in the 21st century: a persistent problem among Canadian infants and mothers. Can Med Assoc J. 2005;172(6):769-770. doi:10.1503/cmaj.050177

17. Christakos S, Ajibade DV, Dhawan P, Fechner AJ, Mady LJ, Vitamin D. Metabolism. Rheum Dis Clin North Am. 2012;38(1):1-11. doi:10.1016/j.rdc.2012.03.003

18. Kinyamu HK, Gallagher JC, Balhorn KE, Petranick KM, Rafferty KA. Serum vitamin $\mathrm{D}$ metabolites and calcium absorption in normal young and elderly free-living women and in women living in nursing homes. Am J Clin Nutr. 1997;65(3):790-797. doi:10.1093/ajcn/65.3.790

19. Hashemipour S, Larijani B, Adibi H, et al. Vitamin D deficiency and causative factors in the population of Tehran. BMC Public Health. 2004;4(1):38. doi:10.1186/1471-2458-4-38 
20. Feizabad E, Hossein-nezhad A, Maghbooli Z, Ramezani M, Hashemian R, Moattari S. Impact of air pollution on vitamin D deficiency and bone health in adolescents. Arch Osteoporos. 2017;12(1):34. doi:10.1007/s11657-017-0323-6

21. Al-Faris NA. High prevalence of vitamin D deficiency among pregnant Saudi women. Nutrients. 2016;8(2):77. doi:10.3390/nu8020077

22. Holvik K, Meyer H, Haug E, Brunvand L. Prevalence and predictors of vitamin D deficiency in five immigrant groups living in Oslo, Norway: the Oslo immigrant health study. Eur J Clin Nutr. 2005;59 (1):57-63. doi:10.1038/sj.ejcn.1602033

23. Hovsepian S, Amini M, Aminorroaya A, Amini P, Iraj B. Prevalence of vitamin D deficiency among adult population of Isfahan City, Iran. J Health Popul Nutr. 2011;29(2):149. doi:10.3329/jhpn.v29i2.7857

24. Jiang L, Xu J, Pan S, Xie E, Hu Z, Shen H. High prevalence of hypovitaminosis D among pregnant women in southeast China. Acta Paediatr. 2012;101(4):e192-e194. doi:10.1111/j.1651-2227.2011.02557.x

25. Nicolaidou P, Hatzistamatiou Z, Papadopoulou A, et al. Low vitamin $\mathrm{D}$ status in mother-newborn pairs in Greece. Calcif Tissue Int. 2006;78(6):337-342. doi:10.1007/s00223-006-0007-5

26. Kull M, Kallikorm R, Tamm A, Lember M. Seasonal variance of 25$(\mathrm{OH})$ vitamin $\mathrm{D}$ in the general population of Estonia, a Northern European country. BMC Public Health. 2009;9(1):22. doi:10.1186/ $1471-2458-9-22$
27. Salek M, Hashemipour M, Aminorroaya A, et al. Vitamin D deficiency among pregnant women and their newborns in Isfahan, Iran. Exp Clin Endocrinol Diabetes. 2008;116(6):352. doi:10.1055/s-20081042403

28. Atiq M, Suria A, Nizami S, Ahmed I. Maternal vitamin-D deficiency in Pakistan. Acta Obstet Gynecol Scand. 1998;77(10):970-973. doi:10.1080/j.1600-0412.1998.771004.x

29. Chapuy M-C, Preziosi P, Maamer M, et al. Prevalence of vitamin D insufficiency in an adult normal population. Osteoporos Int. 1997;7 (5):439-443. doi:10.1007/s001980050030

30. Contreras-Manzano A, Villalpando S, Robledo-Pérez R. Vitamin D status by sociodemographic factors and body mass index in Mexican women at reproductive age. Salud Publica Mex. 2017;59(5, sepoct):518-525. doi:10.21149/8080

31. Renzaho AM, Halliday JA, Nowson C. Vitamin D, obesity, and obesityrelated chronic disease among ethnic minorities: a systematic review. Nutrition. 2011;27(9):868-879. doi:10.1016/j.nut.2010.12.014

32. Hill AB. The environment and disease: association or causation? Proc R Soc Med. 1965;58(5):295. doi:10.1177/003591576505800503
Nutrition and Dietary Supplements

\section{Publish your work in this journal}

Nutrition and Dietary. Supplements is an international, peerreviewed, open access journal focusing on research into nutritional requirements in health and disease, impact on metabolism and the identification and optimal use of dietary strategies and supplements necessary for normal growth and development. The journal welcomes submitted papers covering original research, basic science,

\section{Dovepress}

clinical \& epidemiological studies, reviews and evaluations, guidelines, expert opinion and commentary, case reports and extended reports. The manuscript management system is completely online and includes a very quick and fair peer-review system, which is all easy to use. Visit http://www.dovepress.com/testimonials.php to read real quotes from published authors. 